\title{
Porous Cu-MOF nanostructures with anticancer properties prepared by a controllable ultrasound-assisted reverse micelle synthesis of Cu-MOF
}

\author{
Reza Akhavan-Sigari ${ }^{1}$, Malihe Zeraati ${ }^{2}$, Mohammadreza Moghaddam-Manesh ${ }^{3}$, Parya Kazemzadeh4, \\ Sara Hosseinzadegan ${ }^{5}$, Narendra Pal Singh Chauhan ${ }^{6}$ and Ghasem Sargazi ${ }^{7 *}$
}

\begin{abstract}
The ultrasonic assisted reverse micelle method (UARM) was used to synthesize $\mathrm{Cu}-\mathrm{MOF}$ from $\mathrm{Cu}\left(\mathrm{NO}_{3}\right)_{2} \cdot 3 \mathrm{H}_{2} \mathrm{O}$ and 2,6-pyridine dicarboxylic acid in a 1:1 molar proportion. It has been characterized using FT-IR, XRD, nitrogen adsorption analysis, SEM and TEM-EDX. The morphology of CU-MOFs was spherical, with an average particle size distribution of less than $100 \mathrm{~nm}$. Using BET analysis, the surface area of Cu-MOF was found to be $284.94 \mathrm{~m}^{2} / \mathrm{g}$. The porous morphology of CU-MOF was also suggested by SEM and TEM analyses. It has anticancer properties against MCF-7 breast cancer cells. Cytotoxicity testing was performed on MCF-7 breast cancer cells using the MTT cell viability assay, and cell proliferation and viability were found to be approximately $24 \%$ higher than the control.
\end{abstract}

Keywords: Cu-MOF, Characterization, Cell viability, Anticancer

\section{Introduction}

Metal organic frameworks (MOFs) are a type of porous material made up of strong bonds between metal ions and organic linkers [1, 2]. MOFs with a careful constituent selection can have a very high surface area, a large pore volume, and excellent chemical stability. By careful selection of constituents, MOFs can exhibit very high surface area, large pore volume, and excellent chemical stability [3]. Research on synthesis, structures and properties of various MOFs has shown that they are promising materials for many applications, such as energy storage, gas storage, heterogeneous catalysis and sensing [4]. Apart from direct use, MOFs have also been used as support substrates for nanomaterials or as sacrificial templates/

\footnotetext{
*Correspondence: g.sargazi@gmail.com

${ }^{7}$ Noncommunicable Diseases Research Center, Bam University of Medical Sciences, Bam, Iran

Full list of author information is available at the end of the article
}

precursors for preparation of various functional nanostructures. Ding and co-workers have reviewed MOFs based nanozymes for the treatment of cancer [5-7].

Unfortunately, cancer is one of the leading causes of death for millions of people worldwide. Cancer biology has advanced significantly in the last decade, but cancer mortality remains high $[8,9]$. Traditional drugs for cancer treatment have limitations such as poor pharmacokinetics, poor biological distribution, and adverse side effects [10]. Chemotherapy is the most commonly used cancer treatment, but it has several drawbacks, the most significant of which are low therapeutic efficiency in the treatment process and side effects on normal cells [8]. Since the 1970s, drug release control in drug delivery has been expanding [10]. Drug delivery systems based on nanoparticles are one of the newer methods in drug delivery systems. Drug delivery systems based on nanoparticles can avoid these issues while also increasing efficiency through targeted drug delivery, controlled 
release, and drug degradation protection. MOFs, d layered double hydroxides (LDHs), graphene oxide (GO), and magnetite are some examples of popular drug delivery systems that use nanoparticles today [8]. Some cases that have been investigated in the use of MOFs as drug delivery systems include excellent surface, thermal and chemical stability, high pore volumes, regular porosity and easy operation. $[8,10]$ Linxin et al. have prepared $\mathrm{Zn}_{2}(\mathrm{EBNB})_{2}(\mathrm{BPY})_{2} \cdot 2 \mathrm{H}_{2} \mathrm{O}$ having drug delivery applications [11]. Numerous biological reports have been reported from organic metal frameworks, including inhibition of human glioma cell growth [12], anticancer activity [13-15], and antimicrobial properties [16-18]. One of the MOFs with high biological properties is $\mathrm{Cu}$ MOF [19-21]. It is worth noting that the true nature of the active sites in many MOFs containing metal ions is saturated with the coordination of organic ligands [22]. $\mathrm{Cu}-\mathrm{MOF}$ has superior antibacterial and anticancer properties [23, 24]. The bactericidal mechanism of $\mathrm{Cu}-\mathrm{MOF}$ is due to the diffusion of $\mathrm{Cu}^{2+}$ ions. In addition, the negative charges of lipoproteins are absorbed into the cell wall, they enter the cell and damage the cell wall, alter the function of the enzymes of the cell wall, or create cell wall holes [25].

In this paper, we describe the synthesis of $\mathrm{Cu}-\mathrm{MOFs}$ using the UARM method, followed by FT-IR, XRD, nitrogen adsorption, SEM, and TEM analyses. Its anticancer activity against MCF-7 breast cancer cells is being studied as well.

\section{Experimental section Materials}

$\mathrm{Cu}\left(\mathrm{NO}_{3}\right)_{2} \cdot 3 \mathrm{H}_{2} \mathrm{O}$ and 2,6 pyridine dicarboxylic acid were purchased from Merck. $\mathrm{C}_{12} \mathrm{H}_{25} \mathrm{NaSO}_{4}$ was purchased from Sigma-Aldrich. Double distilled water (DDW) was used in each experiment.

\footnotetext{
Method

$\mathrm{Cu}\left(\mathrm{NO}_{3}\right)_{2} \cdot 3 \mathrm{H}_{2} \mathrm{O}$ (Merck, 98\%) and 2, 6 pyridine dicarboxylic acid (Merck, 99\%) are mixed with 1:1 mmol dissolved in $25 \mathrm{~mL}$ of DDW during the preparation of the samples using the ultrasonic assisted reverse micelle method. The resulting solution was added to a mixture of $0.077 \mathrm{mmol}$ of sodium lauryl sulphate $\left(\mathrm{C}_{12} \mathrm{H}_{25} \mathrm{NaSO}_{4}\right)$ as a surfactant (Sigma, 99\%) and $8 \mathrm{~mL}$ of $\mathrm{C}_{6} \mathrm{H}_{14}$ as solvent. The resulting mixture was then stirred for $1 \mathrm{~h}$ at $85{ }^{\circ} \mathrm{C}$. The resulting solution was placed in the ultrasonic device and exposed to ultrasonic irradiation under optimal conditions, which included an ultrasonic duration of $21 \mathrm{~min}$, a power of $175 \mathrm{~W}$, and an ultrasonic temperature of $40{ }^{\circ} \mathrm{C}$. Cu-MOF crystals form after $30 \mathrm{~min}$ and are separated by centrifugation and washed with DMF.
}

\section{Characterization}

The X-ray diffraction (XRD) employed for characterization and determination of the crystalline structure and phases during the synthesis of $\mathrm{Cu}-\mathrm{MOF}$. To achieve this aim, a powder X-ray diffractometer (Expert MPD, pananalytical, $\mathrm{CuK} \alpha=0.154 .6 \mathrm{~nm}$ ) were used in the range of $2 \theta=4-30$ degree with the step width of 0.05 degree. Scanning electron microscope (SEM, model Em 3200, china KyKy corporation) utilized for investigation of the surface morphology. Fourier transform infrared (FT-IR; SHIMADZU FT8400 spectrometer) with a Bruker- tensor 27 series was utilized for determination of vibrational frequency of the prepared samples in the range of 500 and $4000 \mathrm{~cm}^{-1}$. Porosities, surface area and pore textural characteristics of samples were determined by adsorption/desorption measures (BET, Belsorp mini II) at $77 \mathrm{~K}$ in $\mathrm{N}_{2}$ atmosphere. The absorbance was read by spectrophotometer (BioTek Instruments, Inc., Bad Friedrichshall, Germany).

\section{Anticancer activities}

Anticancer activity of $\mathrm{Cu}-\mathrm{MOF}$ was evaluated using MCF-7 breast cancer cells and the MTT cell viability assay according previously reported methods $[26,27]$. MCF-7 cells were isolated from the pleural effusion of a 58-year-old woman with metastatic disease. In pellet culture system consisted of control medium including RPMI 1640, 10\% FBS and $100 \mu \mathrm{L}$ of penicillin G/ streptomycin mixtures, cells were cultured for a period of 2 weeks. During cell culture, cell passaging was performed by trypsinization and washing was by phosphatebuffered saline. The cells with density of $1.2 \times 10^{4}$ (cells/ well) were seeded in 96-well plates and for $24 \mathrm{~h}$ incubated in condition of $37{ }^{\circ} \mathrm{C}$ and $5 \% \mathrm{CO}_{2}$. With concentrations of $5,10,20,40,80,120$ and $200 \mu \mathrm{g} / \mathrm{mL}$ of $\mathrm{Cu}-\mathrm{MOF}$, cells were treated for 24 and $48 \mathrm{~h}$. Then, the medium was then removed and $50 \mu \mathrm{L} /$ well of MTT solutions $(2 \mathrm{mg} /$ $\mathrm{mL}$ in PBS) and $150 \mu \mathrm{L} /$ well of fresh medium were added and incubated for $4 \mathrm{~h}$. Finally, after removing the MTT solutions, to solubilize the formazan crystals, $200 \mu \mathrm{l}$ of DMSO was added and at $570 \mathrm{~nm}$, the absorbance was read using a spectrophotometer.

\section{Results and discussion}

TEM image was used to investigate the topographical study of $\mathrm{Cu}-\mathrm{MOF}$, as shown in Fig. 1. It is clear that the morphology of $\mathrm{Cu}-\mathrm{MOF}$ was porous and spheri$\mathrm{cal}$ and the average particle size distribution is about $50 \mathrm{~nm}$. As a result, the anticancer properties of the sample were investigated. Figure 2 depicts the phase formation and purity of the samples as determined by X-ray diffraction. The sample pattern belongs to $\mathrm{Cu}-\mathrm{MOF}$, 


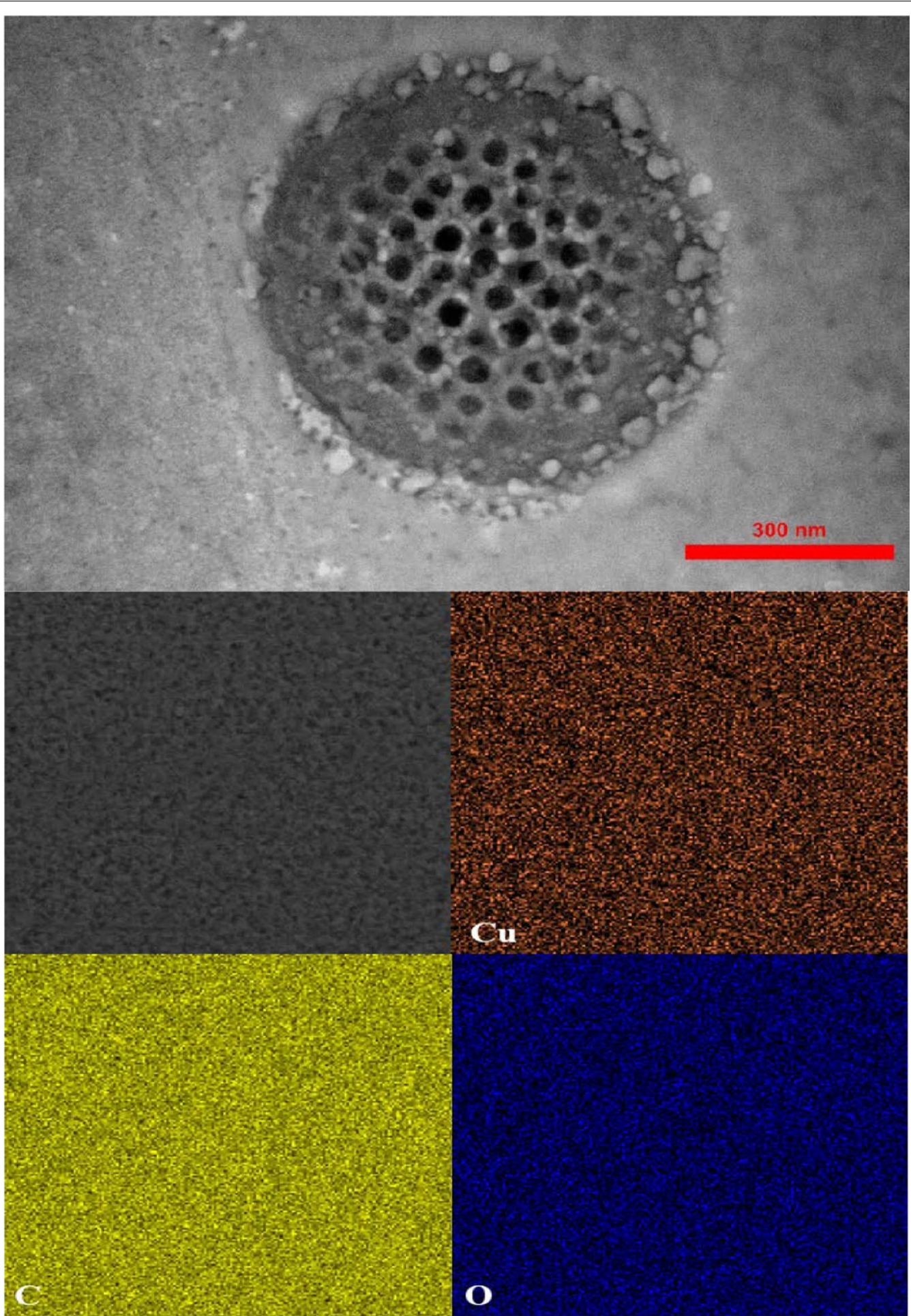

Fig. 1 TEM image of the CU-MOF and its mapping

the peaks marked with a circle at $31^{\circ}, 37^{\circ}, 43^{\circ}, 52^{\circ}, 59^{\circ}$, and $77^{\circ}$ for $\mathrm{Cu}-\mathrm{MOF}$ (JCPDS01-072-0075) [28, 29]. The crystallite size was calculated to be $45 \mathrm{~nm}$ using the
Debye-Scherrer formula $(D=0.9 \lambda / \beta \cos \theta$, where crystal size is expressed by $\mathrm{D}, \mathrm{X}$-ray wavelength is expressed by $\lambda$ and Braggs angle in radians is given by $\theta$ is the, and full 


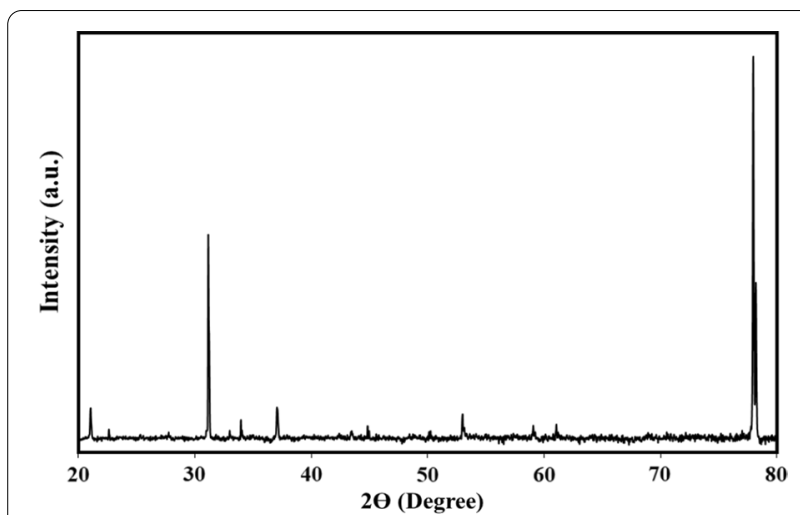

Fig. 2 The X-ray diffraction pattern of Cu-MOF

width at half maximum (FWHM) of the peak in radians is expressed by $\beta$.

The FTIR spectrum of $\mathrm{Cu}-\mathrm{MOF}$ is depicted in Fig. 3. Surface water is present in the $\mathrm{Cu}-\mathrm{MOF}$ structure, and as a result, the $\mathrm{O}-\mathrm{H}$ broad stretching band appears at $3358 \mathrm{~cm}^{-1}$. [30, 31] The weak bands at 2355 and $2099 \mathrm{~cm}^{-1}$ are attributed to COO stretching vibrations present in 2,6-pyridine dicarboxylic acid which serves as organic linker present in $\mathrm{Cu}-\mathrm{MOF}$. The bands appeared at $1632 \mathrm{~cm}^{-1}$ is attributed $\mathrm{C}=\mathrm{O}$ stretching vibrations [16]. The strong absorption bands at 1095 and 1152 corresponds to the asymmetric and symmetric $\mathrm{C}-\mathrm{O}$ stretching [32, 33]. Absorption bands at 872 and $995 \mathrm{~cm}^{-1}$ are attributed to $\mathrm{C}-\mathrm{H}$ symmetric and asymmetric stretching vibrations [34]. The peaks observed between 451 and $616 \mathrm{~cm}^{-1}$ are attributed to $\mathrm{Cu}-\mathrm{O}$ stretching in $\mathrm{Cu}-\mathrm{MOF}$ $[35,36]$. According to the FTIR spectrum, the final structures of $\mathrm{Cu}-\mathrm{MOF}$ nanostructures are suggested in Fig. 4.

The nitrogen adsorption/desorption results of $\mathrm{Cu}-\mathrm{MOF}$ structures at $77 \mathrm{~K}$ are shown in Fig. 5 It (Fig. 5) depicts isotherms of the type (I) in the IUPAC classification, which is an example of microporous materials. [37] The early isotherm's dramatic increase and high $\mathrm{N}_{2}$ uptake indicate a high proportion of microporous. Furthermore, the amount of microporous is very low because the samples' isotherms in the high pressure region show no obvious hysteresis and tail. [38] In addition, the calculated $\mathrm{N}_{2}$ adsorption/desorption isotherms were related to textural parameters. The surface area of $\mathrm{Cu}-\mathrm{MOF}$ measured using BET analysis was $284.94 \mathrm{~m}^{2} / \mathrm{g}$. As a result, the high surface area and porosity of this sample are determined by $\mathrm{N}_{2}$ uptake by $\mathrm{Cu}-\mathrm{MOF}$.

$\mathrm{Cu}$-MOF cytotoxicity was tested on MCF-7 breast cancer cells and the results are shown in Fig. 6. Based on the results of Fig. 6, after $48 \mathrm{~h}$ with high concentrations of $\mathrm{Cu}-\mathrm{MOF}(200 \mathrm{~g} / \mathrm{mL})$, cell proliferation and viability were observed to be approximately $24 \%$ higher than the control. The $\mathrm{IC}_{50}$ value for exposure of $\mathrm{Cu}-\mathrm{MOF}$ at $24 \mathrm{~h}$, $131 \mu \mathrm{g} / \mathrm{mL}$ was obtained and following at $48 \mathrm{~h}, 109 \mu \mathrm{g} /$ $\mathrm{mL}$ was obtained. Therefore, breast cancer cell survival was dependent on concentrations of $\mathrm{Cu}-\mathrm{MOF}$ and time of incubation.

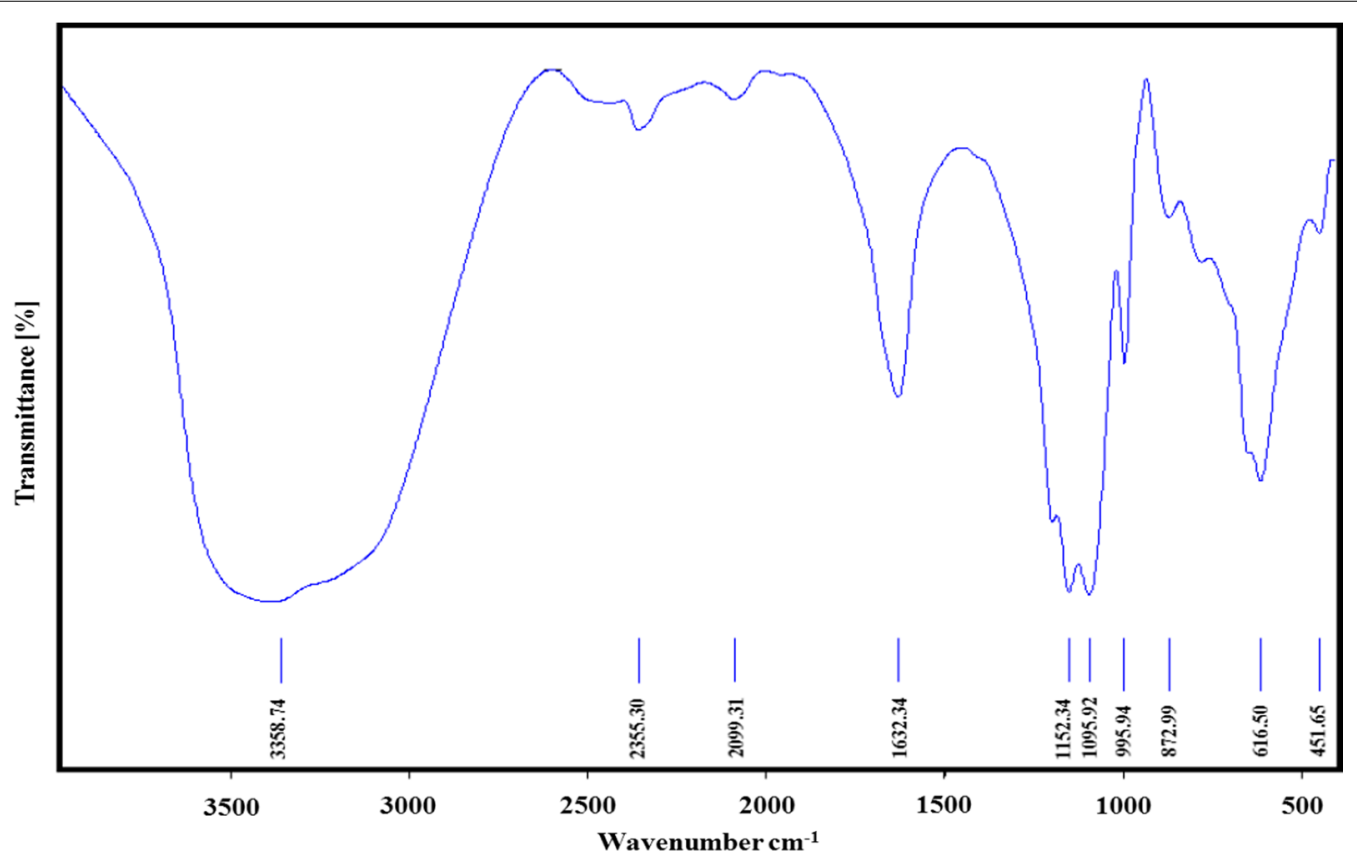

Fig. 3 The FTIR spectrum of Cu-MOF 
$\begin{array}{ll}\text { Akhavan-Sigari et al. BMC Chemistry } & \text { (2022) 16:10 }\end{array}$

Page 5 of 7
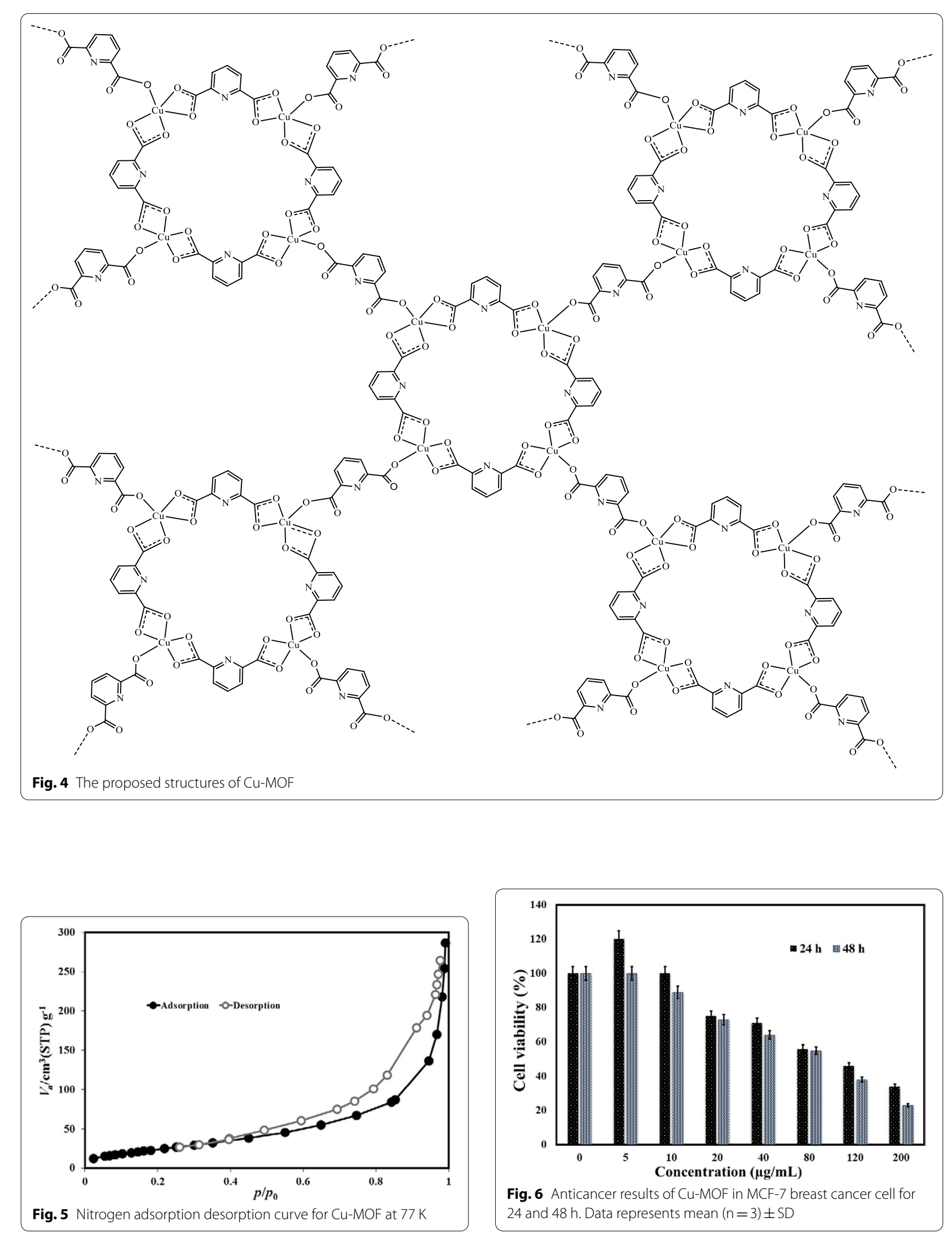


\section{Conclusion}

$\mathrm{Cu}-\mathrm{MOF}$ was prepared using UARM method and it was further characterized by FT-IR, XRD, SEM and nitrogen adsorption/desorption analysis. It has shown reasonably good anticancer activities against MCF-7 breast cancer cells. In summary, the synthesized $\mathrm{Cu}$ MOF exhibited anti-cancer properties against MCF-7 breast cancer with an $\mathrm{IC}_{50}$ value of $109 \mu \mathrm{g} / \mathrm{mL}$ in $48 \mathrm{~h}$ and viability about $24 \%$ with the highest test concentration $(200 \mu \mathrm{g} / \mathrm{mL})$ was obtained at $48 \mathrm{~h}$.

\section{Acknowledgements}

The authors would like to acknowledge from the Bam University of Medical Sciences.

\section{Authors' contributions}

RA-S: methodology, software, visualization. MZ: methodology, software, writing-original visualization. MM-M: methodology, software, visualization. $\mathrm{SH}$ : writing - reviewing and editing investigation. PK: writing - reviewing and editing investigation. NPSC: writing - original, visualization, writing-reviewing and editing investigation. GS: conceptualization, methodology, software, writing —original, visualization, writing — reviewing and editing investigation, data curation, validation, supervision. All authors read and approved the final manuscript.

\section{Funding}

There is no specific funding.

\section{Availability of data and materials}

The datasets used and/or analyzed during the current study available from the corresponding author on request.

\section{Declarations}

\section{Ethics approval and consent to participate}

We confirm all relevant ethical guidelines have been followed, and any necessary IRB and/or ethics committee approvals have been obtained. All methods were used in accordance with relevant guidelines and regulations. Also, we confirmed that all experimental protocols were approved by the Ethics Licensing Committee of the Bam University of Medical Sciences (no. 06 on 17/03/2021). MCF-7 cells were isolated from the pleural effusion of a 58-year-old woman with metastatic disease. In addition, informed consent was obtained from all study participants.

\section{Consent for publication}

Not applicable.

\section{Competing interests}

There is no competing interests.

\section{Author details}

${ }^{1}$ Department of Neurosurgery, University of Nebraska Medical Center, Tuebingen, Germany. ${ }^{2}$ Department of Materials Engineering, Shahid Bahonar University of Kerman, 761694111 Kerman, Iran. ${ }^{3}$ Petrochemistry and Polymer Research Group, Chemistry and Petrochemistry Research Center, Standard Research Institute, Tehran, Iran. ${ }^{4}$ Department of Chemistry, Lorestan University, Khorramabad, Iran. ${ }^{5}$ Department of Chemistry, Faculty of Science, University of Sistan and Baluchestan, Zahedan, Iran. ${ }^{6}$ Department of Chemistry, Faculty of Science, Bhupal Nobles' University, Udaipur, Rajasthan, India. ${ }^{7}$ Noncommu nicable Diseases Research Center, Bam University of Medical Sciences, Bam, Iran

Received: 13 October 2021 Accepted: 28 February 2022

Published online: 05 March 2022
References

1. James SL. Metal-organic frameworks. Chem Soc Rev. 2003;32:276-88.

2. Zhu L, Liang G, Guo C, Xu M, Wang M, Wang C, Zhang Z, Du M. A new strategy for the development of efficient impedimetric tobramycin aptasensors with metallo-covalent organic frameworks (MCOFs). Food Chem. 2022;366: 130575.

3. Furukawa H, Cordova KE, O'Keeffe M, Yaghi OM. The chemistry and applications of metal-organic frameworks. Science. 2013. https://doi.org/ 10.1126/science.1230444.

4. Tansell AJ, Jones CL, Easun TL. MOF the beaten track: unusual structures and uncommon applications of metal-organic frameworks. Chem Cent J. 2017:11:1-16.

5. Ding SS, He L, Bian XW, Tian G. Metal-organic frameworks-based nanozymes for combined cancer therapy. Nano Today. 2020;35: 100920.

6. Ji X, Hou C, Gao Y, Xue Y, Yan Y, Guo X. Metagenomic analysis of gut microbiota modulatory effects of jujube (Ziziphus jujuba Mill.) polysaccharides in a colorectal cancer mouse model. Food Funct. 2020:11:163-73.

7. Tang W, Wan S, Yang Z, Teschendorff AE, Zou Q. Tumor origin detection with tissue-specific miRNA and DNA methylation markers. Bioinformatics. 2018;34:398-406.

8. Pooresmaeil M, Namazi H. Facile preparation of $\mathrm{pH}$-sensitive chitosan microspheres for delivery of curcumin; characterization, drug release kinetics and evaluation of anticancer activity. Int J Biol Macromol. 2020;162:501-11.

9. Yan S, Yan J, Liu D, Li X, Kang Q, You W, Zhang J, Wang L, Tian Z, Lu W. A nano-predator of pathological MDMX construct by clearable supramolecular gold (I)-thiol-peptide complexes achieves safe and potent antitumor activity. Theranostics. 2021;11:6833.

10. Sun L-L, Li Y-H, Shi H. A ketone functionalized Gd (III)-MOF with low cytotoxicity for anti-cancer drug delivery and inhibiting human liver cancer cells. J Cluster Sci. 2019;30:251-8.

11. Linxin D, Song L, Xuehua SJ. The properties of MOF-Zn 2 (EBNB) 2 (BPY) $2 \cdot 2 \mathrm{H} 2 \mathrm{O}$ and its basic study of loading methadone. BMC Chem. 2020;14:1-8.

12. Hu YJ, Li YM, Zheng K, Zhang WH, Liu YL, Yang H. Construction of a Zn (II)-containing MOF for highly selective detection of picric acid and inhibition of human glioma cell growth. J Mol Str. 2020;1202: 127359.

13. Huang J, Pu X-Y, Liu Z, Cao X-Y, Fu J. A 2-fold interpenetrating Zn (II)-MOF: sensitive detection of Fe $3+$ ion and anti-cancer activity on breast cancer through high intensity focused ultrasound. J Inorg Organomet Polym Mater. 2021;31:2209-17.

14. Yan Z, Li X, Fan Q, Bai H, Wu S, Zhang ZF, Pan L. A water-stable and biofriendly Zn-MOF with pyrazine decorated pores as 5-Fu delivery system to induce human ovarian cancer cells apoptosis and abrogate their growth. J Mol Str. 2020;1204: 127477.

15. Song B-H, Ding X, Zhang Z-F, An G-F. Efficient drug delivery of 5-fluorouracil by a biocompatible $Z n$-metal-organic framework nanostructure and anti-liver cancer activity study. J Iran Chem Soc. 2019;16:333-40.

16. Akbarzadeh F, Motaghi M, Chauhan NP, Sargazi G. A novel synthesis of new antibacterial nanostructures based on Zn-MOF compound: design, characterization and a high performance application. Heliyon. 2020;6: e03231.

17. Restrepo J, Serroukh Z, Santiago-Morales J, Aguado S, Gómez-Sal P, Mosquera ME, Rosal R. An antibacterial Zn-MOF with hydrazinebenzoate linkers. Eur J Inorg Chem. 2017;2017:574-80.

18. Gwon K, Han I, Lee S, Kim Y, Lee DN. Novel metal-organic frameworkbased photocrosslinked hydrogel system for efficient antibacterial applications. ACS Appl Mater Interfaces. 2020;12:20234-42.

19. Chen D, Li B, Jiang L, Li Y, Yang Y, Luo Z, Wang J. Pristine Cu-MOF induces mitotic catastrophe and alterations of gene expression and cytoskeleton in ovarian cancer cells. ACS Appl Bio Mater. 2020;3:4081-94.

20. Xuan Z, Zhan Y, Song G, Liu B. Two Cu (II) co-ordination polymers: anti-cancer activity on melanoma by reducing cancer cell proliferation, migration, and invasion ability, inorganic and nano-metal. Chemistry. 2021;51:239-45.

21. Azizabadi O, Akbarzadeh F, Danshina S, Chauhan NP, Sargazi G. An efficient ultrasonic assisted reverse micelle synthesis route for Fe304@ Cu-MOF/core-shell nanostructures and its antibacterial activities. J Solid State Chem. 2021;294: 121897. 
22. Zou R-Q, Sakurai H, Han S, Zhong R-Q, Xu Q. Probing the lewis acid sites and $\mathrm{CO}$ catalytic oxidation activity of the porous metal-organic polymer [Cu (5-methylisophthalate)]. J Am Chem Soc. 2007;129:8402-3.

23. Pires AS, Batista J, Murtinho D, Nogueira C, Karamysheva A, Luísa Ramos M, Milne BF, Tavares NT, Gonçalves J, Gonçalves AC. Synthesis, characterization and evaluation of the antibacterial and antitumor activity of HalogenatedSalen Copper (II) complexes derived from camphoric acid. Appl Organomet Chem. 2020. https://doi.org/10.1002/aoc.5569.

24. Gu L, Wang P, Zhong Q, Deng Y, Xie J, Liu F, Xiao F, Zheng S, Chen Y, Wang G. Copper salt-catalyzed formation of a novel series of triazole-spirodienone conjugates with potent anticancer activity. RSC Adv. 2017;7:9412-6.

25. Wang Y, Wang F. Post-translational modifications of deubiquitinating enzymes: expanding the ubiquitin code. Front Pharmacol. 2021;12:1434

26. Moghaddam-manesh M, Beyzaei H, Majd MH, Hosseinzadegan S, Ghazvini K. Investigation and comparison of biological effects of regioselectively synthesized thiazole derivatives. J Heterocycl Chem. 2021. https:// doi.org/10.1002/jhet.4278.

27. Ji P, Wang L, Wang S, Zhang Y, Qi X, Tao J, Wu Z. Hyaluronic acidcoated metal-organic frameworks benefit the ROS-mediated apoptosis and amplified anticancer activity of artesunate. J Drug Target. 2020;28:1096-109.

28. Süsse PJ. Verfeinerung der kristallstruktur des malachits, $\mathrm{Cu} 2(\mathrm{OH}) 2 \mathrm{CO} 3$. Acta Crystallogr. 1967;22:146-51.

29. Riccò R, Linder-Patton O, Sumida K, Styles MJ, Liang K, Amenitsch H, Doonan CJ, Falcaro PJ. Conversion of copper carbonate into a metal-organic framework. Chem Mater. 2018;30:5630-8.

30. Lin J, Wang D, Chen D, Ge Q, Ping G, Fan M, Qin L, Shu K. Preparation and enhanced photocatalytic performance of one-dimensional ZnO nanorods. Environ Prog Sustain Energy. 2015;34:74-80.

31. Kaur R, Kaur A, Umar A, Anderson WA, Kansal SK. Metal organic framework (MOF) porous octahedral nanocrystals of Cu-BTC: Synthesis, properties and enhanced adsorption properties. Mater Res Bull. 2019;109:124-33.

32. Lin S, Song Z, Che G, Ren A, Li P, Liu C, Zhang J. Adsorption behavior of metal-organic frameworks for methylene blue from aqueous solution. Microporous Mesoporous Mater. 2014;193:27-34.

33. Azad FN, Ghaedi M, Dashtian K, Hajati S, Pezeshkpour V. Ultrasonically assisted hydrothermal synthesis of activated carbon-HKUST-1-MOF hybrid for efficient simultaneous ultrasound-assisted removal of ternary organic dyes and antibacterial investigation: Taguchi optimization. Ultrason Sonochem. 2016;31:383-93.

34. Ji X, Cheng $Y$, Tian J, Zhang S, Jing Y, Shi M. Structural characterization of polysaccharide from jujube (Ziziphus jujuba Mill.) fruit. Chem Biol Technol Agric. 2021;8:1-7.

35. Stehfest K, Boese M, Kerns G, Piry A, Wilhelm C. Fourier transform infrared spectroscopy as a new tool to determine rosmarinic acid in situ. J Plant Physiol. 2004;161:151-6.

36. Mai NXD, Yoon J, Kim JH, Kim IT, Son HB, Bae J, Hur J. Hybrid hydrogel and aerogel membranes based on chitosan/prussian blue for photofenton-based wastewater treatment using sunlight. Sci Adv Mater. 2017:9:1484-7.

37. Rouquerol J, Rouquerol F, Llewellyn P, Maurin G, Sing KS. Adsorption by powders and porous solids: principles, methodology and applications. Cambridge: Academic press; 2013.

38. Javanbakht S, Pooresmaeil M, Namazi H. Green one-pot synthesis of carboxymethylcellulose/Zn-based metal-organic framework/graphene oxide bio-nanocomposite as a nanocarrier for drug delivery system. Carbohyd Polym. 2019;208:294-301.

\section{Publisher's Note}

Springer Nature remains neutral with regard to jurisdictional claims in published maps and institutional affiliations.
Ready to submit your research? Choose BMC and benefit from:

- fast, convenient online submission

- thorough peer review by experienced researchers in your field

- rapid publication on acceptance

- support for research data, including large and complex data types

- gold Open Access which fosters wider collaboration and increased citations

- maximum visibility for your research: over $100 \mathrm{M}$ website views per year

At BMC, research is always in progress.

Learn more biomedcentral.com/submissions 